\title{
РИТМІЧНА ОРГАНІЗАЦІЯ, РИМУВАННЯ ТА ЗВУКОВА ГАРМОНІЯ УКРАЇНСЬКИХ ПАРЕМІЙ
}

Малюга Н. М. Ритмічна організація, римування та звукова гармонія українських паремій.

У статті проаналізовано ритмічний малюнок українських паремій, особливості їх римування; закцентовано на звуковому оформленні прислів”їв, взаємодії фонетичних засобів у створенні художньо досконалої форми, що сприяє кращому запам'ятовуванню паремій у процесі комунікації.

Ключові слова: паремія, прислів'я, рима, ритм, алітерація, асонанс.

() Н. Є. Коломієць, Н. В. Яременко, 2012. - 194 - 
Малюга Н. Н. Ритмическая организация, рифма и звуковая гармония украинских паремий.

В статье осуществлен анализ ритмического рисунка украинских паремий, особенностей их рифмы, акцентировано внимание на звуковом оформлении пословиц, взаимодействии фонетических средств в создании художественно совершенной формы, что способствует лучшему запоминанию паремий в процессе коммуникации.

Ключевые слова: паремия, пословица, рифма, ритм, аллитерация, ассонанс.

Maluga N. M. Rhythmical organization, rhyme and sound harmony of Ukrainian paremias.

In the article the analysis of rhythmical pattern of Ukrainian paremias and peculiarities of their rhyme is accomplished; attention is paid to sound organization of proverbs, interaction of phonetical tools while creating an artistically perfect form. It helps to better memorize paremias in the process of communication.

Key words: paremia, proverb, rhyme, rhythm, alliteration, assonance.

Визначальною ознакою паремій $\epsilon$ не лише здатність у сконденсованому вигляді містити глибокий зміст, а й художньо досконала форма, їм притаманна евфонічна спайка лексичних компонентів. Прислів'я, як і взагалі народна поетична мова, визначається виразною ритмічністю і здебільшого також зримованістю. У римі відбивається музичне чуття народу, його підсвідоме прагнення до повноти й краси звуку. Рима надає формі прислів'я викінченості, робить його відносно нерухомим і водночас таким, що легко запам'ятовується.

Ефект впливу тексту на читача досягається за допомогою звукового оформлення, що складає одне ціле з ритмом і значенням й окремо від них не може впливати на слухача. Як пише Ф. Медведєв, «звукова гармонія та інші художні властивості прислів”їв, як і всіх майже типів фразеологічних одиниць, посилюють духовне переживання людини, сприяють формуванню іï різних видів вищих емоційних процесів - соціальних, інтелектуальних, естетичних» [2, с. 52].

Для прислів”ів характерною $є$ взаємодія різних фонетичних засобів, проте найбільш акцентними в реалізації стилістичних функцій уважаються рима, асонанс та алітерація, які слугують ритмічній організації та римуванню паремій, що, у свою чергу, сприяє їх кращому запам'ятовуванню у процесі комунікації.

Як стверджує М. Пазяк, «естетична сторона прислів'я реалізується в яскравій виразності, різноманітності й цілеспрямованості художніх засобів, досконалості форми, ритму і римування» [4, с. 182], однак ритміка та римування українських паремій, джерела походження їх метрики, зв'язки іiі 3 народнопісенним і силабо-тонічним віршуванням, а також спорідненість звучання прислів”їв та приказок 3 ритмізованою фольклорною прозою 
(казками, легендами, анекдотами тощо) ще чекають на спеціальні дослідження [4, с. 10]. Завдання свого дослідження вбачаємо в систематизації фонетичних особливостей пареміологічних одиниць.

Автори літературознавчого словника-довідника наголошують: «Рима як звукове, а не графічне явище охоплює ритмічний акцент $<\ldots>$, тісно пов'язується з ритмомелодикою, лексикою, синтаксисом, строфікою віршованого мовлення. Попри те, що їй відводиться чільна роль у ліричній композиції та строфотворенні, вона виконує й інші функції: естетичну, мнемотехнічну, магічну, ритмоінтонаційну, жанровизначальну» [1, с. 592-593].

Рима може формуватися за рахунок кількості складів (силабічна), принципу наголошеності та ненаголошеності (силабо-тонічна), наголосів у певному відрізку (тонічна), «термін «рима» означає фактичне розташування наголошених та ненаголошених складів у конкретному віршовому розмірі силабо-тонічної системи, динаміку акцентної ритмоінтонації у тонічній системі та верлібрі» [1, с. 596].

Українська силабо-тоніка спирається на природне мовне чергування наголошених та ненаголошених складів, які зумовлюють специфіку віршового розміру. Ритміка прислів'їв не вкладається в рамки силабо-тонічної системи. Тільки в частині 3 них через увесь текст проходять одного типу стопи, наприклад:

Свиня у барлозі, а птах у дорозі

(ритмічна схема:

$\left.\mathrm{U}-^{\prime} \mathrm{U}\left|\mathrm{U}-^{\prime} \mathrm{U}\right| \mathrm{U}-^{\prime} \mathrm{U} \mid \mathrm{U}-^{\prime} \mathrm{U}\right)$ - амфібрахій;

Коли Бог не велить, то нехай не болить

(ритмічна схема:

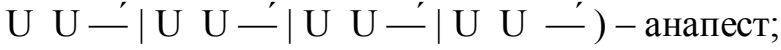

За цุаря Горошка, коли хліба не було ні трошки

(ритмічна схема:

пірихіями;

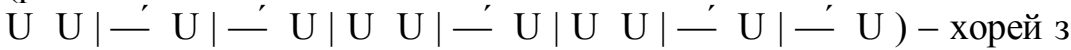

Як розвернеться на весну лист, то підемо всі в свист

(ритмічна схема:

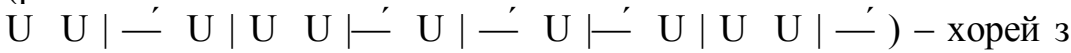
пірихіями;

Вбери й пенька, то стане за Панька

(ритмічна схема:

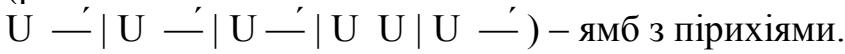

() Н. М. Малюга, 2012. 
У чистому вигляді і трискладові, i двоскладові стопи трапляються рідко. Тут більшу роль відіграє однакова кількість тонічних наголосів, їх симетрія в обох частинах прислів'я: Дере коза лозу, а вовк козу, а вовка мужик, а мужика пан, а пана юриста, а юристу чортів триста; Дере коза лозу, а вовк козу, а мужик вовка, а nin мужика. При дослідженні ритміки прислів’їв учені надають перевагу не розподілу на стопи, а інтонаційним наголосам, які симетрично розташовуються в обох частинах. Цією властивістю ритмізовані прислів'я наближаються до ритмомелодики народних пісень: I до плуга, і до рала, і до хлопщзів дала драла; Ні до плуга, ні до рала - на музики гоча драла; Гай, гай, та й не дома, де сі рушу, все солома; Рад би неба прихилити, та не хилиться (хорей з пірихіями). У таких пареміях повністю збережений первісний пісенний ритм.

Розглядаємо ритм як впорядкований рух. Співвимірність чергування подібних явищ (частинок, на які розпадається впорядкований рух) «відбилася на специфіці версифікації, на пii квантитативній та квалітативній системах» [1, с. 595]

Інтонаційно-ритмічні можливості паремій дуже великі, часто вони не вкладаються в звичні для силабо-тонічного віршування схеми. Багатьом прислів'ям властиві сполучення різнопланових ритмів: прихованих, довільних, жвавих, ослаблених, піднесено сильних. У більшості паремій ритмічний малюнок характеризується переходами й змінами на межі частин, наприклад:

Сякий-такий, аби був

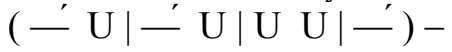

аби хліба роздобув

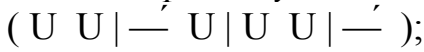

І жив - не любила, і вмер - не тужсла

( $\mathrm{U} \perp^{\prime} \mathrm{U}\left|\mathrm{U} \perp^{\prime} \mathrm{U}\right| \mathrm{U}-\mathrm{U} \mid \mathrm{U}-\mathrm{U}$ );

і на лавиі лежить, $і$ не буду любить

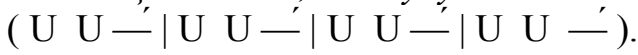

Ритмічно організовані частини взаємодіють 3 ритмічно не організованими, і це одна з основних причин художньої довговічності прислів'їв [3, с. 40]. Не треба абсолютизувати ритм: він добрий тоді, коли діє разом з усім комплексом образних засобів. У багатьох випадках сам народ порушує монотонну ритмічність, уводячи у прислів'я прозові інтонації (з'являються так звані ритмічні перебої). 
3-поміж найбільш поширених форм ритміки й римування можна виділити такі: двочастинне просте прислів'я 3 двома тонічними наголосами, цезурою між частинами, римуванням (На кожну гадюку держи кріпко руку; Свиня рилом волокла $i$ «добрий день» не рекла; 3 поганої собаки хоч клочок шерсті взяти та́ки), складне прислів'я, що має дві частини, які між собою римуються (рідше - чотири частини, тоді римуються 1 - 2, 3 - 4) (Літо дає коріння, а осінь-насіння; Не тепер по гриби ходити, але восени, як будуть родити; Як є пліт, то нема воріт, а як є ворота, то немає плота), хоч можуть бути й без римування (Коваль коня кує, а жаба ногу наставляє; Як загнав на слизьке, то й про підкови згадав; Моє діло, як кажуть, мірошницьке: запусти та й мовчи; Не вважайте, люди добрі, щчо я швецьь: говоріть зі мною, як з простим). Рівномірність ритму, кількість тонічних наголосів у частинах порушуються, коли треба передати раптовість діiі, iii завершення. Тоді ритмічний малюнок набуває іншого вигляду (Літом сякий-такий бур'янець, а хліба буханець та й ситий чоловік). У наведеному прикладі перші дві частини прислів'я між собою римуються, третя частина без рими, на неї падає основний смисловий наголос. Зміна ритму в останній частині невипадкова, вона вимагає до себе більшої уваги, несе основне смислове навантаження [3, с. 41].

Варіювання на фонетичному та морфологічному рівні не відіграє істотної ролі у прислів'ях, вони поступово уніфікуються, пристосовуючись до літературної мови. Виняток становлять ті випадки, коли особливості вимови треба зберегти для милозвучності, римування тощо [4, с. 190]: Собака собакою остане, хоч і хвоста не стане.

Прислів'ям притаманні й приблизні, дієслівні рими, хоч ця приблизність не помічається в мовленні, оскільки вона компенсується змістом та словесною образністю. Навіть прислів'я 3 кволими дієслівними римами можуть мати сильні образи, які поглинають усю увагу читача, наприклад: Яблуко од яблуні хоч $і$ далеко одкотиться, та все ж корінчиком притулиться.

За будовою паремійні рими бувають чоловічі (окситонні) (Зав'яз пазурець - $і$ пташиі кінець; Більше землю удобряй - будеш мати урожай), жіночі (парокситонні) (Гора хоч не родить, та й з хліба не зводить; Яка грушка, така й юшка), дактилічні ( поважаємо, як є в віщо, то вмочаємо, а ні в віщзо - вибачаємо; Де борошно, там і порошно); парно-одиничні (Де багато пташок, там нема комашок; Колись і в наше віконце засвітить сонце), попарні (Як 
молодим бував, то сорок вареників їав, а тепер хамелю-хамелю $i$ насилу п'ятдесят умелю; Бути бичку на личку, а коровиі на вірьовиі).

У пареміях часто римуються власні імена: (Глянь на вид, та ци кажи, щзо Свирид; Не розумний тим Денис, щзо великий має ніс; Казав Наум - візьми на ум; Хома не без ума: не б’є жінку, та тешу; У мене Хома - й добра нема;їхав до Хоми, а заӥхав до куми; Коли не Кирило, то не пхай туди рило; Дурного Кирила і Химка побила; На тобі, Данило, щзо мені не мило; Не вмер Данило, болячкою вдавило; У кожного Мусія своя затія; Пустив Бог Микиту на волокиту; Голодній Гапці хліб на гадці; Який Сава, така й слава; На вовка неслава, а їсть овець Сава; Бідному Савці нема долі ні на печі, ні на лавці: на печі печуть, на лавці січуть; Той же Савка, та на других санках; Зустрівся Яким з таким; Катерина Василю не давала киселю; Катерина Дем'яну не попустить бур'яну; За изаря Гороха (Митрохи), як людей було трохи; За цุаря Панька (Тимка), як земля була тонка: пальцем проткни й води напийся; До милої (любоі) Оришки й на край світу пішки; Говорив Мирон рябої кобили сон; Наша Галя, як краля, та тільки душа невмивана; Це тая Солоха, щуо кури полоха; На Бога надія й на кума Матвія; У всякої Палажкки свої замашки; Не для Гриця паляниця; Не микайся, Грицю, на дурницю, бо дурниця тобі боком вилізе; Кожна птиця знайде свого Гриця; Труби, Грицю, в рукавицю; Куди пішов Лесь, то все весь; Парочка - Мартин да Одарочка; Сповідали Іллюху від n'ят до вуха; Забагатів Кіндрат - забув, де його брат; Такої ласки дістану $і$ в Параски; Розумна Парася на все здалася; Саврадим п'яний як дим; Сиди, Векло, ще не смеркло; Сиди, Тетяно, бо ще рано Бісів Юхим - $i$ з води вийде сухим; Сякий-такий Пантелій, а все-таки веселій).

Рима для прислів’їв не є самоціллю, художньої вартості без неї вони не втрачають, наприклад: Ссть $і$ в нього блохи, да нікому вигнати; Послухавши жука, завжди в гною будеш; Кого гадюка укусить, той $i$ черв'яка боїься та ін. Однак аналіз наведеного ілюстративного матеріалу не дозволяє засумніватися у виваженому висновку пареміолога й пареміографа М. Пазяка: «Рими цементують прислів’я в одне ціле, примушують образи триматися поряд. Вони допомагають підкреслити паралелізм частин, зіставити значення, включені в римовані слова. Іноді в прислів'ях рими бувають настільки точні й виразно змістовні, що навіть самі по собі без контексту здатні психологічно насторожувати, будити фантазію, давати роботу мозку <..> Своїми асоціаціями рими можуть натякати на зміст прислів’їв. Вони завершують 
думку, дають можливість відчути на слух емоційні й смислові ознаки, виявляють пластику слова, його евфонію» [4, с. 196].

Важливу роль у звучанні прислів'їв відіграють алітерації та асонанси. Народ влучно імітує деякі явища природи або своєї діяльності: Як у поле, Анцю в боці коле, як до танцю, вже не коле Анцю; Собака собачі хвоста не одкусить; Скажений пес і на свого господаря кидається; Залізо іржа з'їає, а заздрий від заздрощів погибає; Як ї, то аж упрів, а як працював, то аж задрімав; Ажс на небі чути, як мухи кашляють; Не годуй коня батогом, а годуй вівсом; Хто глибоко оре, той злото виоре; Одчиняйтеся, врата, для нашого брата; Бик на щэо звик, за тим бринить; Гірке ремесло - леміш та чересло. Слово змушує розум уявляти подобу звуку, кольору тощо. Так, акустичне враження від африкати ц нагадує звуки, які видобувають з ударних музичних інструментів; за допомогою ритмічної повторюваності щілинних звуків, зокрема с, створюється своєрідний звуковий акомпанемент змістові: домінує мінорний настрій, навіюється відчуття незворотності, розпачу й т. ін.; повтор артикуляційно складного дрижачого p, особливо в поєднанні з проривними, допомагає майже фізично відчути зусилля, спрямовані на подолання чогось складного чи важкого; голосні заднього ряду асоціюються з чимось великим, розміром, глибиною, наповненням тощо. Звукова подібність починає усвідомлюватися як смисловий зв'язок.

Створення звукового малюнка за рахунок асоціації розширює тематичне поле зображуваного. Звуки, ритмомелодика тексту заявляють про себе не формально, а в асоціативному зв'язку із семантикою. Знаний пареміолог М. Пазяк зазначає: «здебільшого гармонія звукових елементів впливає на мистецьку думку опосередковано, без явного зв'язку зі змістом, вона тільки допомагає краще виділити зміст прислів'я» [4, с. 197], звукова структура паремії спрямована «на глибоке й високохудожнє відтворення дійсності» [там само].

Спостерігаємо прийом паронімічної атракції, що базується на семантичному зближенні в контексті слів, псевдоморфеми яких позбавлені об'єктивної генетичної та словотвірної спорідненості: $\mathrm{He}$ бачила ковалиха лиха; Без догляду немає ладу; Гори, гори та на пироги; Молодого рака покарав старий рак, то оба лізуть $і$ днесь так (у двох останніх виділених випадках слід читати у зворотному напрямку, «навпаки»). Звуковий повтор послідовно починає характеризувати слова як смислові одиниці тексту. Близькість фонетичних обрисів зумовлює 
співвіднесення слів як смислових одиниць і виникнення між ними різних семантичних зв'язків. Звукова атракція сприяє виокремленню, виділенню додаткового значення звукоряду.

Отже, у структурі паремій - художніх творах малої форми, що походять 3 усної народної творчості - знаходять реалізацію різноманітні мовні засоби, зокрема фонетичні. До фонетичних засобів відносять римовані співзвуччя, алітерацію й асонанс, які сприяють стійкості паремій, їхньому запам'ятовуванню.

\section{Література}

1. Літературознавчий словник-довідник / Р. Т. Гром’як, Ю. І. Ковалів та ін. - К. : ВЦ «Академія», 1997. - $752 \mathrm{c}$.

2. Медведєв Ф. П. Українська фразеологія. Чому ми так говоримо / Ф. П. Медведєв. [2-е вид., стереотипне]. - Х. : Вища школа. 1982. - 232 с.

3. Пазяк М. М. Прислів'я та приказки : Природа. Господарська діяльність / АН УРСР. Інститут мистецтвознавства, фольклору та етнографії ім. М. Т. Рильського ; Упоряд. М. М. Пазяк; Відп. ред. С. В. Мишанич. - К. : Наукова думка, 1989. -480 с.

4. Пазяк М. М. Українські прислів'я та приказки. Проблеми пареміології та пареміографії / М. М. Пазяк. - К. : Наукова думка, 1984. - 204 с.

Стаття надійшла до редакції 19.10.2012 p. 